\title{
MID-MESOZOIC LEAVES FROM NEAR IDA BAY, SOUTHERN TASMANIA, AUSTRALIA
}

\author{
by William D. Tidwell, Jong-Heon Kim and Tatsuaki Kimura
}

(with three text-figures and three plates)

TIDWELL, W.D., KIM, J.H. \& KIMURA, T., 1987 (30:vi): Mid-Mesozoic leaves from near Ida Bay, southern Tasmania, Australia. Pap. Proc. R. Soc. Tasm., 121: 159-170, 3 pl. https://doi.org/10.26749/rstpp.121.159 ISSN 0080-4703. Department of Botany and Range Science, Brigham Young University, Provo, Utah 84602,

U.S.A.; Department of Astronomy and Earth Sciences, Tokyo Gakugei University, Koganei, Tokyo, 184 Japan (J.H. Kim is a Korean student studying with Professor Kimura).

Several leaf specimens from a locality in southern Tasmania are described. They are assigned to Coniopteris websterii sp.nov., Cladophlebis indica (Oldham \& Morris) Sahni \& Rao, Pachypteris sp. cf. indica (Oldham \& Morris) Bose \& Roy, Otozamites sp., Pterophyllum? sp. and Conites sp. The specimen of Otozamites sp. is also partially petrified and, thus, gives some indication of its internal tissues. These genera and species suggest a mid-Mesozoic, rather than a Tertiary, age for this locality.

Key Words: Mid-Mesozoic, Tasmania, Coniopteris, Cladophlebis, Pachypteris, Otozamites, Ptilophyllum, Pterophyllum, Conites, Osmundacaulis.

\section{INTRODUCTION}

A locality south of Ida Bay in southern Tasmania has yielded numerous specimens of fossil plants (pl. I, fig. 1). This locality lies a few hundred metres to the east and west of the Lune River Road immediately north of its junction with the Leprena Track (text-fig. 1). The plant remains include two osmundaceous species, Osmundacaulis nerii Tidwell and Jones (1987) and $O$. jonesii Tid well (1987), a fossil tree fern Cibotium tasmanense Gould (1972), unidentified permineralized conifer wood and the fossilized leaf material of this report. The permineralized plant materials and the leaf impressions were collected together but were not in situ. The rock matrix having the leaf impressions also contains petrified fern petioles assignable to Cibotium tasmanense Gould and an, as yet, unnamed tree fern. This suggests that the fossil plants from this locality came from the same horizon. Gould (1972) considered the strata from whence these plant fossils were derived as possibly Tertiary.

Although the fossil leaves described in this report are preserved in three dimension, they lack cuticle. In some, however, the outline of the epidermal cells is impressed upon the specimens. These leaf specimens were collected by Neri Webster of Bicheno, Tasmania and Ross Jones of Blackmans Bay, Tasmania. The specimens are deposited in the Tasmanian Museum and Art Gallery.

\section{SYSTEMATIC DESCRIPTION}

\section{Filicales}

\section{Dicksoniaceae}

Genus Coniopteris Brongniart, 1849

Coniopteris websterii sp.nov.

Pl. II, figs 1, 2; pl. III; text-figs 2B, 3C(i \& ii)

Material

Holotype - Z2296, Paratype - Z2295.

\section{Diagnosis}

Leaves mostly fertile; main rachis, $1.5 \mathrm{~mm}$ thick bearing pinnae at $6 \mathrm{~mm}$ in tervals; main rachis and pinna rachis rounded; pinnae, thick, leathery, about $15 \mathrm{~mm}$ long, arising alternately from main rachis; first pinnules of pinna arising opposite, later pinnules alternate on the two sides; pinnules of one pinna "commonly" overlapping those of the next and adjacent pinnules of the same pinna; first pinnule consists of short stalk, forking after approximately $0.2 \mathrm{~mm}$ into an upward pointing fertile branch and forward and outward pointing sterile branches forked into two to four, lobes projecting over main rachis; upper fertile appendages alternate, consist of long stalk, $1 \mathrm{~mm}$ long and terminal sorus; sorus and ind usium circular cordate in lateral compression, about $2 \mathrm{~mm}$ wide by $1-1.6 \mathrm{~mm}$ high; basal sori generally smaller and hemispherical; sori lying in flat plane or slightly tilted; indusium thick, $200 \mu \mathrm{m}$ wide, marked 


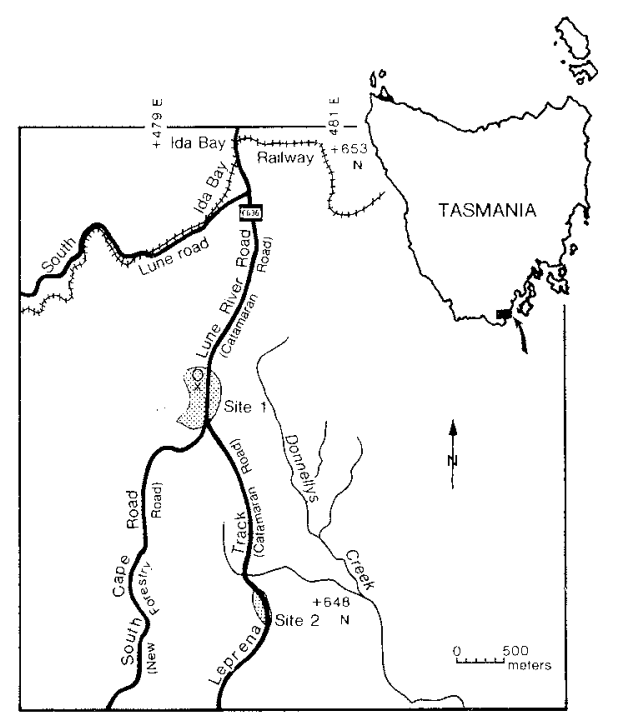

FIG. 1 - Map of southern Tasmania showing collecting sites for fossil plants. Road names in parenthesis are those used on Gould's (1972) index map. $O=$ collection locality for Otozamites $s p$. (Modified from Leprena 4818, edition 1, 1985; Tasmania 1:25000 Landsmap.)

externally by differential preservation; margins entire; sporangia numerous, not projecting beyond the edge of the indusium, rather small, about $200 \mu \mathrm{m}$ wide, annulus oblique, nearly complete; no spores were observed.

\section{Etymology}

The specific epithet honours Neri Webster who collected the specimens of this fern and who has contributed so much to this study.

\section{Remarks}

The holotype is fragmental and consists of a single fertile pinna with seven fertile appendages. Sterile leaves are similar to the sterile branches of the first fertile pinnules.

Coniopteris websterii is similar to $C$. margaretae Harris (1961) and C. simplex (L. \& H.) Harris (1961). It is distinguished in having larger sori than $C$. simplex and having alternate rather than opposite pinnules. The upward pointing fertile branch of the first pinnules in $C$. websterii differs from the forward pointing fertile branch of these pinnules in C. margaretae. Coniopteris websterii is unlike other species of Coniopteris. It, however, resembles Gonatosorus sphenopteroides Brick (1937) and G. nathorsti Raciborski (1894). Shorter sterile lobes and a much smaller sorus of $G$. sphenopteroides separates it from $C$. websterii and broader, undivided sterile lobes and a smaller sorus separates $G$. nathorsti from $C$. websterii.

Halle (1913) described four species of Coniopteris from the Jurassic or Early Cretaceous (Stipanicic \& Bonetti 1970) of Graham Land, and Douglas (1973) described fertile leaves or sterile parts of four species of this genus from the Early Cretaceous of Victoria, Australia, but none is similar to $C$. websterii. Based on sterile foliage, Coniopteris nanopinnata Douglas has been transferred to Gleichenites (Drinnan \& Chambers 1986).

\section{Incertae Sedis}

Genus Cladophlebis Brongniart, 1849

Cladophlebis indica (Oldham \& Morris) Sahni \& Rao 1933

Pl. I, figs 4, 7; pl. II, figs 5, 6; text-fig. $2 \mathrm{~A}$

\section{Material}

$$
\text { Z2297, Z2298. }
$$

\section{Diagnosis}

Five sterile pinna fragments with rather stout pinna axis up to $1 \mathrm{~mm}$ wide; pinnules falcatedeltoid in shape, tapering strongly towards apex, typically $11 \mathrm{~mm}$ long by $5 \mathrm{~mm}$ wide at the base; apices obtusely or subacutely pointed; close, suboppositely or alternately attached by entire base at an angle of $50^{\circ}$; margins entire, slightly recurved; laminae contiguous near base; midrib is distinct, extending to tip; lateral veins katadromic, 8-9 pairs, forking once; basiscopic basal vein occasionally forked twice.

\section{Comparisons}

The leaves of only a few reported Cladophlebis species resemble Cladophlebis indica in having entire, falcate pinnules and singly-forked lateral veins (Retallack 1980). Among these species similar to $C$. indica are $C$. nebbensis (Brgn.) Nathorst (1878), C. acuta Fontaine (1889), C. grahamii Frenguelli (1947), and C. oblonga Halle (1913). The latter two species were reported from Jurassic or Early Cretaceous strata of Graham Land. Cladophlebis nebbensis, although poorly preserved, has pinnules that appear less falcate, less tapered and more obtusely pointed, whereas, the pinnule apices in C. acuta are more acute than in C. indica. Cladophlebis grahamii differs from $C$. indica by the former species having its basal lateral vein occasionally forking twice and the basal acroscopic margins of its pinnules being subauriculate. 


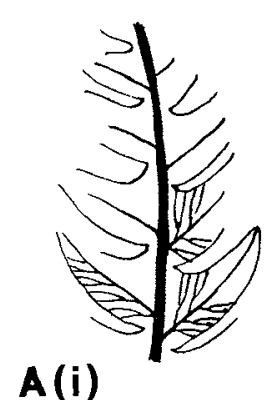

A(ii)

A(i)
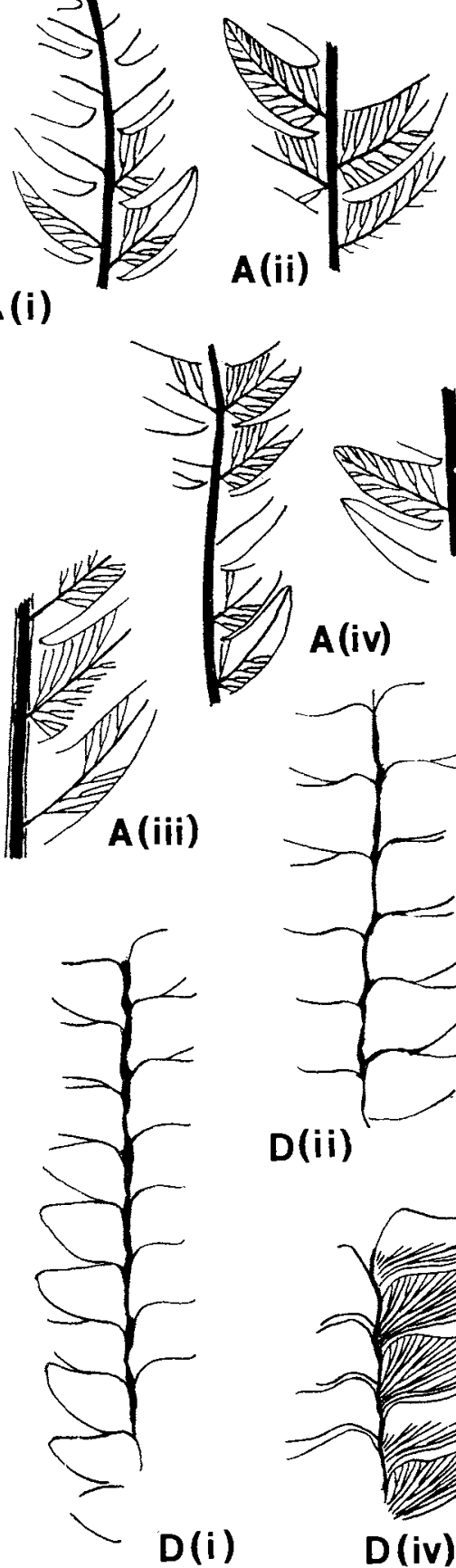

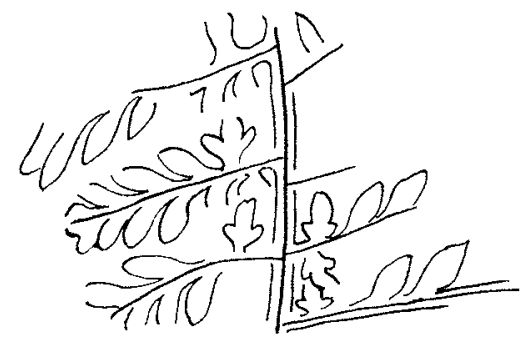

$\mathrm{C}(\mathrm{i})$

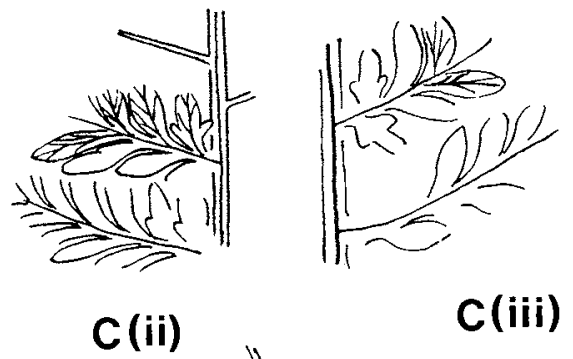

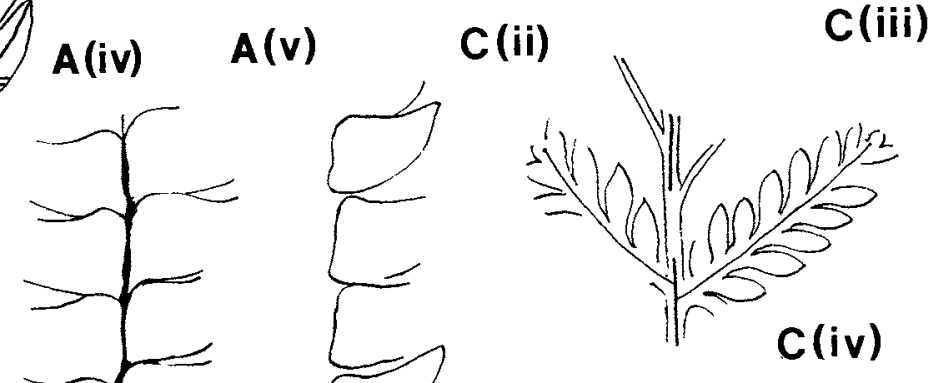

FIG. $2 A(i-v)$ - Cladophlebis indica (Oldham \& Morris) Sahni \& Rao showing various forms of pinnules (i); from Z2298. (ii-v) from Z2297; x 2; $2 B$ - Coniopteris websterii sp. nov. from Z2296; x 2; C(i-v) Pachypteris $s p$. cf. indica (Oldham \& Morris) Bose \& Roy showing venation (i,vi,v), from Z2301; (ii, iii) from Z2300; $x$ 2; $2 D(i-i v)$ - Otozamites sp., showing pinna-form and venation from $Z 2302 ; x 2$. 
Cladophlebis oblonga is closest to $C$. indica and is distinguished from this latter species by its lesstapering pinnule apices (Retallack 1980). Based upon some fertile specimens, Bose \& Sah (1967) transferred $C$. indica to Todites indicus. Retallack (1980), however, considered them separate taxa and, noted that when fertile fronds of $C$. indica are collected, they will probably be osmundaceous.

The present pinna fragments are similar to those of Cladophlebis australis (Morris) Seward (1904) and C. biformis Drinnan and Chambers. Cladophlebis australis is known extensively from Triassic strata in the Southern Hemisphere (see Herbst 1978, Retallack 1980, 1983). In fact, the species name australis was given originally by Morris (1845) to Tasmanian Triassic leaves. Cladophlebis australis, in a strict sense, has relatively erect, falcate pinnules with entire or slightly undulating margins (Retallack 1983). Cladophlebis biformis was reported from the Lower Cretaceous Koonwarra Fossil Bed on the South Gippsland Highway south of Leongatha, Victoria (Drinnan \& Chambers 1986). In C. biformis, the entire margined, falcate pinnules have acute apices and are distichously arranged. Both of these species have lateral doubly-forking veins throughout their pinnules which contrasts with the single-forking veins of C. indica. Cladophlebis australis, as loosely identified in the past, has been incorrectly regarded as the most widespread, long-ranging and common fern of the Gond wanan Mesozoic (Retallack 1983). However, as pointed out by Retallack (1983), if Morris' original illustrations are followed then $C$. australis would be restricted to Middle and Late Triassic rocks of eastern Australia and Argentina.

Cladophlebis indica is a long-ranging taxon that has been found in both New Zealand and India (Retallack 1980).

Some species of Cladophlebis have been regarded as members of the Osmundaceae (Townrow 1963, Harris 1961, Andrews 1970). Cladophlebis indica may also belong to this family. Petrified fern stems assignable to Osmundacaulis fossilized with this foliage (Tidwell 1987, Tidwell \& Jones 1987), suggest such assignment may be correct (Medwell 1954, Douglas 1969).

\section{Pteridospermales}

Genus Pachypteris Brongniart, 1828 Pachypteris sp. cf. indica (Oldham \& Morrîs) Bose \& Roy 1967

Pl. II, fig. 4; text-figs 2C(i-v)

\section{Material}

Z2299, Z2300, Z2301.

\section{Diagnosis}

Leaf at least bipinnate with a rather thick rachis, $1 \mathrm{~mm}$ wide with a median groove, ultimate pinnae arise alternately at an angle of about $50^{\circ}$; pinnae elongate-oblong in outline, $15 \mathrm{~mm}$ long and up to $8 \mathrm{~mm}$ wide, $5-8$ pairs of pinnules arising katadromically together with a terminal one. Pinnules generally short-oblanceolate or ovate in outline; apices obtusely pointed or blunt, pinnules attached to pinna axis at a narrow angle, decurrent, forming a narrow web, $0.5 \mathrm{~mm}$ wide along both sides of pinna axis; typically $5 \mathrm{~mm}$ long and up to $1.5 \mathrm{~mm}$ wide; veins Sphenopteris-type; three pairs of simple or once forked lateral veins arise from midrib; basal pinnules give rise to a pair of deeply dissected lobes; these pinnules attached at a wide angle or perpendicular; veins invisible; a single shallow lobe present only on the acroscopic side in some pinnules (text-fig. $2 \mathrm{C}(\mathrm{ii})$ ); no pinnule at very base of pinna or on rachis between adjacent pinnae; cuticle not preserved.

\section{Remarks}

Specimens consist of five fragments of isolated leaves. Although detailed cuticular features of these leaves are unknown, they appear to be similar to the seed fern Pachypteris. Epidermal cells of the upper epidermis were observed in the pinnule impressions of these specimens (textfig. 3B). These cells appear to have had straight walls and are almost isodiometric in shape. However, they are slightly elongated over the veins. No stomata were observed. Because of their incompleteness, it is difficult to make a definite identification to species of these leaves. However, they are sufficiently similar to Pachypteris indica to tentatively assign them as Pachypteris sp. cf. indica. Pachypteris indica has been reported from the Middle to Upper Jurassic Kachchh localities (Bose \& Banerji 1984) and the Lower Cretaceous Jabalpur Series (Bose \& Roy 196 ) of India.

\section{Comparisons}

Pachypteris specifica Feistmantel known from the Lower Cretaceous of India (Bose \& Banerji 1984 ) and $P$. lanceolata Brongniart reported from the Middle Jurassic of Yorkshire (Harris 1964) are similar to the Tasmanian Pachypteris specimens. However, they are distinguished from each other by their size, the presence of pinnules on the main rachis and their respective venation.

Pachypteris sp. cf. indica is also similar to $P$. crassa Townrow, and P. austropapillosa Douglas. Pachypteris crassa was collected from Upper Triassic sediments at the Langloh coal mine, 


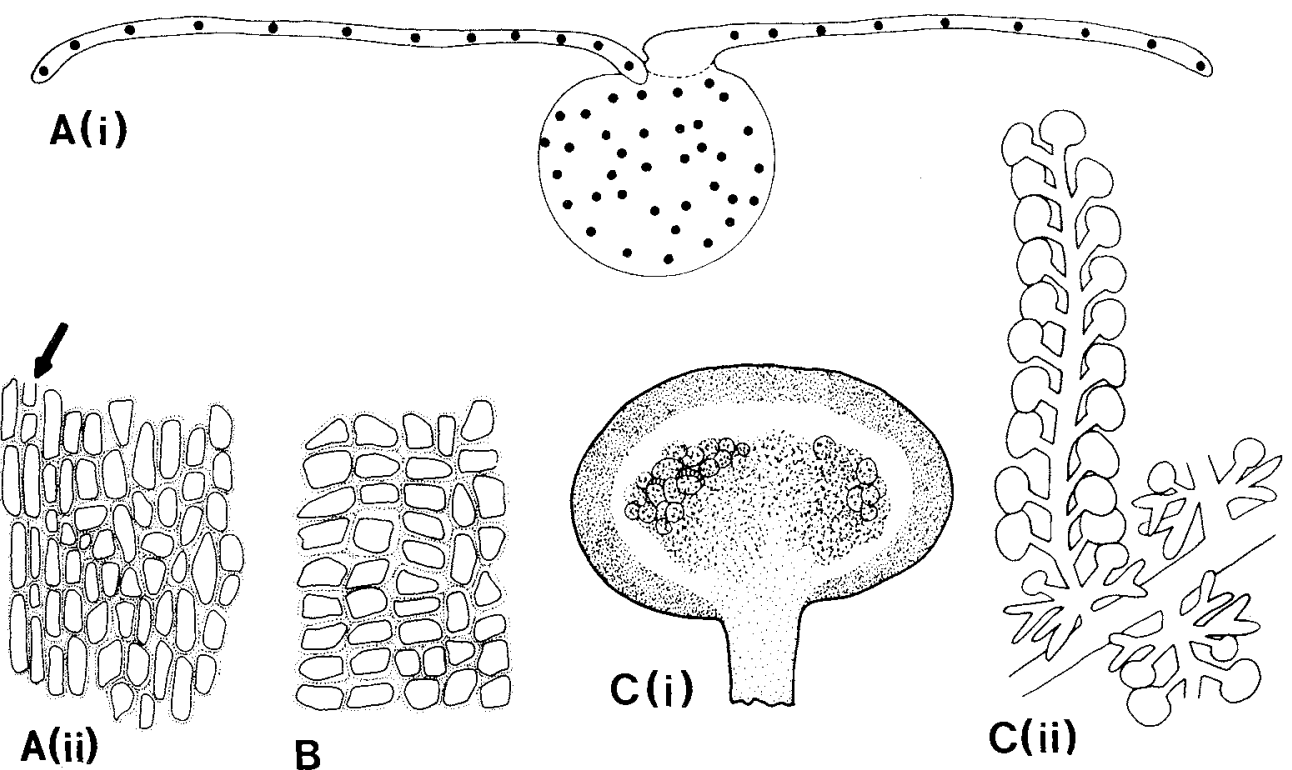

FIG. $3 A(i-i i)$ - Otozamites sp. (i) cross-section of petiole and lamina. Black dots represent vascular bundles and veins, Z2302; $\times 20$. (ii) epidermal cells of the upper lamina and a vein (arrow); $x 10 ; 3 B-$ Pachypteris sp. cf. indica (Oldham \& Morris) Bose \& Roy. Epidermal cells of the upper lamina, Z2301; $x$ $100 ; 3 C$ (i-ii) - Coniopteris websterii sp. nov. (i) enlargement of sorus containing sporangia; $x$ 10. (ii) showing distribution of sori, Z2296; $x 2.5$.

Hamilton, Tasmania (Townrow 1965). Pachypteris crassa differs from Pachypteris sp. cf. indica by being larger, having slightly contracted pinnule bases and having pinnules that are joined together by a wing of tissue along the pinna rachis. This wing gives a bilateral symmetry to the rachis of $P$. crassa that does not appear in $P$. sp. cf. indica.

Pachypteris austropapillosa, described from the Lower Cretaceous of Victoria (Douglas 1969), differs from P. sp. cf. indica by being larger, having undulate pinnule margins, rounded apices and more perpendicular aspects in its pinnule attachment.

Sterile and fertile pinnules in Coniopteris frutiformis Douglas (1973) are attached to each other. The sterile pinnules of this species are similar to $P$. sp. cf. indica and its fertile pinnules are like $C$. websterii. However, the sterile pinnules of $C$. frutiformis lack a midrib which is present in $P$. sp. cf. indica and the sterile pinnules of $C$. websterii are dissected, unlike those of C. frutiformis. The fertile pinnules of $C$. websterii are continuous to the apex of the pinna (pl. III) whereas upper portions of the fertile pinna of $C$. frutiformis are sterile.

\section{Bennettitales}

Genus Otozamites Braun, 1842 Otozamites sp.

Pl. II, figs 2, 3; text-figs 2D(i-iv), 3 A(i-ii)

Material

Z2302

\section{Diagnosis}

Leaves nearly parallel-sided for the most part, elongated, up to $15 \mathrm{~mm}$ wide; ape $\mathrm{x}$ and base unknown; pinnae falcate-deltoid with rather expanded acroscopic basal angle; acroscopic margin concave, basiscopic margin mostly convex, contracted and slightly decurrent near base; typically $7.5 \mathrm{~mm}$ long, $2.5 \mathrm{~mm}$ wide at middle; pinna apex obtusely or subacutely pointed; pinnae close, overlapping, suboppositely attached to upper edge of slender, round rachis (up to $2.5 \mathrm{~mm}$ wide) by lower portion of inner edge of pinna base at a right angle; upper half of base free; expanded acroscopic basal angle often overlapping succeeding basiscopic pinna base; veins originated from the attachment of pinna, five in number at base, upper three fork 
twice and radiate to the acroscopic angle and margin; lower two fork twice, each ending at the distal basiscopic margin; cuticle not preserved.

\section{Remarks}

This specimen of Otozamites sp. is characterized by its small size and elongated leaf composed of falcate-deltoid pinnae with strongly marked and free acroscopic angle.

The fossil is preserved in an unusual manner. It is intermediate between a cast and a petrification. The specimen has the external impressions of the Otozamites leaves, but the bulk of the foliage is still embedded in is matrix which was sectioned.

In cross-section, Otozamites sp. consists of round rachides with attached "gull-wing" shaped pinnae(text-fig. 3A(i)). Although poorly preserved, various components of the rachides can be observed. The epidermal and hypodermal tissues of the rachides cannot be separated and the ground tissue inside these structures appears to be parenchymatous. However, the outline of these cells is not often seen and most of it is disorganized into a brown humus-like substance. Complete layers of thick-walled mechanical tissue similar to sclerenchyma surround the vascular bundles. Up to forty vascular bundles occur in two rather vague circular bands. The inner circle is situated within an outer circle which is near the epidermal-hypodermal region. The other bundles are randomly distributed. No resin cavities appear in the rachides or in the mesophyll of the pinna.

Bundle configuration is not known in other species of Otozamites, but it is known in some species of the Bennettitales such as Ptilophyllum amarjolense Bose, $P$. sahnii Gupta and Sharma and Dictyozamites sp. (Bose \& Kazat 1970a, $1970 \mathrm{~b})$. In these, the bundles are arranged in double U's which are unlike the more or less scattered bundle configuration in the rachides of Otozamites sp.

Vascular bundles can be observed in the lamina as black dots but their a natomy is difficult to determine. The upper and lower cuticles appear to be thin and about the same thickness. It is difficult to distinguish the cuticle from the epidermis. No attached trichomes were noted. Stomata were not recognized on the upper surface of the lamina, which seems to be covered by an unbroken epidermis. In some areas, stomata can be seen in the lower epidermis, lying in the lamina between bundles. Although not perfectly preserved, the guard cells seem to be at an oblique angle usual in gymnosperms (Stopes 1910). Surfaces of the guard cells are thinly cutinized. The apertures do not appear to be arched. No hypodermal layer was detected.

The mesophyll, although not well preserved, appears to have been well developed and consisted of one, possibly two, layers of closely packed cylindrical cells $12 \mu \mathrm{m}$ wide and $50 \mu \mathrm{m}$ long. Their walls appear thin. Throughout the remainder of the leaf, the mesophyll cells are round to irregularly shaped.

Outlines of polygonal epidermal cells are preserved in impressions of the leaves (text-fig. $3 \mathrm{~A}(\mathrm{ii})$ ). The cells over the rachis are rectangular to occasionally rectangular spindle-shaped $(30-40 \mu \mathrm{m}$ long by $15 \mu \mathrm{m}$ wide) and round hair bases appear to be present. Stomates were not observed.

Impression of the upper epidermis shows the epidermal cells between the veins are rectangular to polygonal and are parallel to subparallel to the veins (pl. I, fig. 6). The cells over the veins are elongated in longitudinal rows and are of a more uniform rectangular shape. Cell walls are moderately marked, rather broad and straight. No evidence of trichome bases is present. Lower epidermis was not observed.

\section{Comparisons}

Specimens from the Boola Boola forest (Lower Cretaceous) that were first described as Otozamites by Douglas $(1962,1963)$ and later transferred to Ptilophyllum (Douglas 1969), resemble this Tasmanian specimen in pinna size, but they are distinguished from each other by the strongly developed acroscopic angle of the pinna in the Otozamites specimen from Tasmania.

This Tasmanian Otozamites species resembles most closely in leaf form and size the species $O$. bengalensis (Oldham \& Morris 1863) Seward (1917) which is, according to Bose \& Kasat (1970a), synonymous with Ptilophyllum cutchense Morris. Otozamites sp. can be distinguished from the above mentioned Indian species by its very different pinna form and by having venation which radiates from the base of the pinnae rather than more or less parallel veins arising from the entire pinna base as in Ptilophyllum.

The small leaves of Ptilophyllum bengalense (Oldham) Schimper from the Liassic plant-bed of North Iran (Kilpper 1968) and Otozamites walkamotaensis Bose \& Zeba-Bano (1978) from Kachchh, India resemble in pinna form those of Otozamites sp. Ptilophyllum bengalense and $O$. walkamotaensis are distinguished from $O$. sp. by their pinnae not being distinctly auriculated, by the venation in $P$. bengalense being coarser, simple or once forked and the higher number of veins $(8-14)$ 
in $O$. walkamotaensis which fork one to three times.

Ptilophyllum spinosum described by Douglas (1969) from the Lower Cretaceous of Victoria, Australia is similar in leaf form, size and pinna form to Otozamites sp., but is distinguished from this latter taxon by its densely crowded veins (ten in number at the base) that fork only once. The Tasmanian leaves were placed in Otozamites instead of Ptilophyllum because of the presence of strongly marked and free acroscopic basal angle in the pinna of the Tasmanian specimens. Based upon this feature, it is likely that Ptilophyllum spinosum Douglas is closer to the genus Otozamites than to Ptilophyllum. It is difficult to distinguish Otozamites from Ptilophyllum by their cuticular characters alone.

There is also a possibility that these Tasmanian leaves might belong to Ctenozamites, but the slight radial divergence of the leaves of $O$. sp. makes it unlikely that they belong to the former genus.

\section{Genus Pterophyllum Brongniart, 1828} Pterophyllum? sp.

$$
\text { Pl. I, figs. 3, } 5
$$

\section{Material}

$$
\text { Z2303 }
$$

\section{Remarks}

The only specimen in this flora that can be assigned to this genus is a single pinna fragment that unfortunately is only represented by its basal part. The pinna is $9 \mathrm{~mm}$ wide at its base and is attached to the side of a slender tachis. It is slightly expanded at its base. The parallel veins arise from the rachis at an angle and are simple and nine in number. The basiscopic veins are bent slightly downwards at their point of origin. Cuticle was not preserved. Because of its incompleteness, this fragment is only provisionally assigned to Pterophyllum.

\section{Gymnosperm - Incertae Sedis \\ Genus Conites Sternberg, 1823 Conites sp.

$$
\text { Pl. I, fig. } 2
$$

\section{Remarks}

Very small cone scales resembling Conites occur in the matrix of the specimen containing Otozamites sp. (Z2302). None of these scales are attached to a cone axis. Based upon size and shape, they most closely approximate the scales of Conites sp. B from India (Bose \& Banerji 1984).

\section{DISCUSSION}

The leaf specimens constituting this report, various osmundaceous species and two genera of tree ferns were collected on the slope and flat areas (Pl. I, fig. 1) east and west of the Lune River Road, north of the junction with the Leprena Track. A basalt, containing siliceous a mygdules and xenoliths of silicified sediment, crops out on the ridge above and west of the locality and extends southwards. Gould (1972) thought the fossil material may have been derived from weathering of the pale, leached sediments interbedded with or just beneath the basalt, or from the xenoliths in the basalt itself. However, the thick vegetational cover obscures the actual original site(s) of the fossil plant remains. As pointed out by Gould (1972), there is not any direct evidence for the age of these sediments. However, based upon a suggested Tertiary age for the basalt, he thought them to be Tertiary. Upper Triassic coal measures containing silicified wood occur north of this fossil locality. Gould (1972) considered the preservation of this Triassic wood to be different from that of the petrified fern he described from the Lune River Road-Leprena Track site (fig. 1). The fossils from this latter locality appear to be too young to be Triassic and are certainly older than Tertiary.

Based upon the occurrence of the pteridosperm Pachypteris and bennettitalean Otozamites, there is little doubt that the geological age of the collecting site for Cibotium tasmanense Gould, Osmundacaulis nerii, $O$. jonesii and the fossil leaf materials comprising this report is Mesozoic. It is difficult to make a precise age determination of the plant bed within the Mesozoic because of the insufficiency of the fossil material.

In comparing this Tasmanian flora with the flora from the Middle Jurassic Walloon Coal Measures of Queensland, none of the fossil plant species reported by Gould $(1974,1981)$ from this strata are the same as those from the Tasmanian locality. Anatomically, Osmundacaulis hoskingii Gould (1973), is the closest, but it differs in various ways from the Tasmanian species (Tidwell 1987 , Tidwell \& Jones 1987). The other species of petrified osmundaceous stems from the Walloon Coal Measures are also different from the Tasmanian axes. These latter species have been transferred to Millerocaulis (Tidwell 1986).

It is most likely that the strata of this Tasmanian plant bed is Late Jurassic-Early Cretaceous 
in age. As presently known, Pachypteris species or pteridospermous plants with small pinnae and pinnules as in the Tasmanian specimens are predominant in the Upper Jurassic and Lower Cretaceous plant beds in India (Bose \& Banerji 1984), Argentina (Archangelsky 1963a, 1963b, 1964) and South Africa (Anderson \& Anderson 1985; their gen. A. sp. A and gen. B. sp. A), and smaller Otozamites (or Ptilophyllum) species such as these from Tasmania are predominant in the Lower Cretaceous plant beds in Australia (Douglas 1969). Because Cladophlebis indica has been recorded from the Upper Triassic to Lower Cretaceous plant beds (Retallack 1980), the sterile fern leaves of this species are useless for precise age determination.

The Osmundacaulis species $(O$. nerii and $O$. jonesii) from this locality are like $O$. hoskingii, but are most similar to O. natalensis (Schelpe 1955) Miller and $O$. atherstonei (Schelpe 1956) Miller from the Lower Cretaceous of South Africa. Erasmus (1978) identified two new species of Osmundacaulis from the Lower Cretaceous of South Africa. The anatomy of these two species is exceptionally close to $O$. nerii, $O$. jonesi $i$ and other, as yet undescribed, osmundaceous species from this Tasmanian locality. The inner and outer sclerotic rings which are found surrounding the petiolar vascular strands in $O$. nerii also occur in one of Erasmus' species. These two species, as well as another Osmundacaulis species ( $O$. lemonii Tidwell), from the Late Jurassic of Utah, are the only taxa with these unique tissues.

Based upon the fossil evidence, this flora appears to be either Late Jurassic or Early Cretaceous and, most likely, Early Cretaceous in age. Because of the lack of angiospermous fossils, this flora is probably from older Lower Cretaceous strata.

\section{ACKNOWLEDGEMENTS}

The authors wish to express appreciation to Neri Webster and Ross Jones for their donation of specimens which made this study posible, to $\mathrm{Dr}$ M.R. Banks of the University of Tasmania for his helpful assistance and patience during this study, and to Dr S.R. Ash of Weber State College and Dr G. Retallack of the University of Oregon for reviewing the manuscript.

\section{REFERENCES}

ANDERSON, J.M. \& ANDERSON, H.M., 1985: PALAEOFLORA OF SOUTHERN AFRICA PRODROMUS OF SOUTH AFRICAN MEGAFLORAS DEVONIAN TO LOWER CRETACEOUS. A.A. Balkema, Rotterdam: 423 pp.

ANDREWS, H.N., 1970: Famille des Osmundaceae R. Brown. In Boureau, E. (Ed.): TRAITE DE PALEOBOTANIQUE, Tome IV, fasc. 1: 250.

ARCHANGELSKY, S., 1963a: Notas sobre la flora fosil de la zona de Tico, Provincia de Santa Cruz. 2 Tres neuvas especies de Mososingeria. Ameghiniana, 3(4): 113-120.

ARCHANGELSKY, S., 1963b: A new Mesozoic flora from Tico, Santa Cruz Province, Argentina. Bull. Brit. Mus. (Nat. Hist.) Geol., London, 8(2): 45-92.

ARCHANGELSKY, S., 1964: Notas sobre la flora fosil de la zona de Tico, Provincia de Santa Cruz. 3. Ruflorina pilifera n.sp. 4. Equisetites sp. Ameghiniana, 3(8): 221-226.

BOSE, M.N. \& BANERJI, J., 1984: The fossil floras of Kachchh. I. Mesozoic megafossils. Palaeobotanist, 33: 1-189.

BOSE, M.N. \& KASAT, M.L., 1970a: The genus Ptilophyllum in India. Palaeobotanist (1972), 19(2): 115-145

BOSE, M.N. \& KASAT, M.L., 1970b: On petrified specimen of Dictyozamites from the Rajmahal Hills, India. Palaeobotanist (1972), 19(3): $248-250$.

BOSE, M.N. \& ROY, S.K., 1967: On the occurrence of Pachypteris in the Jabulpur Series of India Palaeobotanist (1968), 16(1): 1-9.

BOSE, M.N. \& SHAH, S.C.D., 1967: Some pteridophytic remains from the Rajmahal Hills, Bihar. Palaeobotanist (1968), 16(I): 12-28.

BOSE, M.N. \& ZEBA-BANO, 1978: On the new species of Otozamites from Kachchh, western India. Palaeobotanist (1981), 27: 227-231.

BRICK, M.I., 1937: La flore Mesozoique du Ferghana Meridoional, II. Fougeres (fin) Equisetinees. Trans. geol. Trust Centr. Asia, Tashkent, 3: $1-75$.

DOUGLAS, J.G., 1962: The occurrence of Otozamites in south-eastern Victoria. Proc. R. Soc. Vict. $75(1): 41-43$

DOUGLAS, J.G., 1963: New bennettitalean leaves from the Mesozoic of eastern Australia. Proc. R. Soc. Vict., 77(1): 197-206.

DOUGLAS, J.G., 1969: The Mesozoic floras of Victoria. Pts 1-2. Geol. Surv. Vict. Mem. 28: 310 pp.

DOUGLAS, J.G., 1973: The Mesozoic floras of Victoria. Pt 3. Geol. Surv. Vict. Mem. 29: 185 pp.

DRINNAN, A.N. \& CHAMBERS, T.C., 1986: Flora of the Lower Cretaceous Koonwarra Fossil Bed (Korumburra Group), South Gippsland, Victoria. Mem. Assoc. Australas. Palaeontols, 3: $1-77$ 
ERASMUS, T 1978: THE ANATOMY ANDEVOLUTION OF OSMUNDACAULIS MILLER EMEND. WITH NOTES ON THE GEOMETRY OF THE XYLEM FRAMEWORK OF THE OSHUNDACEOUS STELE. Unpubl. Ph.D. thesis, Univ. Pretoria: 155 pp.

FONTAINE, W.M., 1889: The Potomac or younger Mesozoic flora. U.S. Geol. Surv. Mon. 15: 1-377.

FRENGUELLI, J., 1947: El genero Cladophlebis y sus representante en la Argentina. An. Mus. La Plata n.s. Paleont. sec. B. Paleobot., 2: 1-74.

GOULD, R.E., 1972: Cibotium tasmanense sp. nov., a fossil tree-fern from the Tertiary of Tasmania. Aust. J. Bot., 20: 119-126.

GOULD, R.E., 1973: A new species of Osmundacaulis from the Jurassic of Queensland. Proc. Linn. Soc. N.S.W., 98(2): 86-94.

GOULD, R.E., 1974: The fossil flora of the Walloon Coal Measures: a survey. Proc. R. Soc. Queensland, $85(3): 33-41$.

GOULD, R.E., 1981: The coal-forming flora of the Walloon Coal Measures. Coal Geology, 1(3): 83-105.

HALLE, T.G., 1913: The Mesozoic flora of Graham Land. Wiss. Ergb. Schwed. Sub-polar Exp. 1901-1903, 3(14): 1-123.

HARRIS, T.M., 1961: THE YORKSHIRE JURASSIC FLORA. I. THALLOPHYTA-PTERIDOPHYTA. British Museum (Natural History), London: $212 \mathrm{pp}$.

HARRIS, T.M., 1964: THE YORKSHIRE JURASSIC FLORA. II. CAYTONIALES, CYCADALES \& PTERIDOSPERMS. British Museum (Natural History), London: $191 \mathrm{pp}$.

HERBST, R., 1978: Revision de las especies australasicas de Cladophlebis (Bgt.). (1). Facena, Corrientes, 2: $3-28$.

KILPPER, K., 1968: Einige Bennettiteen-Blatter aus dem Lias von Karmozd-Zirab (N-Iran). J. Linn. Soc. (Bot.), 61(384): 129-135.

MEDWELL, L.M., 1954: A review and revision of the flora of the Victorian Lower Jurassic. Proc. $R$. Soc. Vict. 65: 63-111.

MORRIS, J., 1845: In PHYSICAL DESCRIPTION OF N.S.W. AND VAN DIEMEN'S LAND.

NATHORST, A.G., 1876(1878?): BEITRAGE ZUR FOSSILEN FLORA SCHWEDENS. UBER EINIGE RHATISCHE PFLANZEN VON PALSJO IN SCHONEN. Stuttgart: $34 \mathrm{pp}$.

OLDHAM, T.\& MORRIS, J., 1863: Fossil flora of the Rajmahal Series in the Rajmahal Hills. Mem. geol. Surv. India Palaeont. indica, Ser.2, 1(1): $1-52$.
RACIBORSKI, M., 1894: Flora Kopalna ogniotrwalych glinck Krakowskich. Czesc. I. Rodniowce (Archaeginiatae). Pam. Mat.-przyr. Akad. Um. Krakow, 18: 143-243.

RETALLACK, G.J., 1980: Middle Triassic megafossil plants and trace fossils from Tank Gully, Canterbury, New Zealand. J. R. Soc. New Zealand, 10(1): 31-63.

RETALLACK, G.J., 1983: Middle Triassic megafossil marine algae and land plants from near Benmore Dam, southern Canterbury, New Zealand. $J . R$. Soc. New Zealand, 13: 129-154.

SAHNI, B. \& RAO, A.R., 1933: On some Jurassic plants from the Rajmahal Hills. J. Asiat. Soc. Beng. N.S., 27(2): 183-208.

SCHELPE, E.A.C.L.E., 1955: Osmundites natalensisa new fossil fern from the Cretaceous of Zululand. Ann. Mag. Nat. Hist., 8( 12): 654-656.

SCHELPE E.A.C.L.E., 1956: Osmundites atherstone - new Cretaceous fern from Cape Province, South Africa. Ann. Mag. Nat. Hist., 9: 330-332.

SEWARD, A.G., 1904: On a collection of Jurassic plants from Victoria. Rec. geol. Surv. Vict., 1: $155-210$

SEWARD, A.G., 1917: FOSSIL PLANTS. III. Cambridge University Press, Cambridge: $656 \mathrm{pp}$.

STIPANICIC, P.N. \& BONETTI, M.I.R., 1970: Posiciones estratigraficas y edads de las principales floras jurasicas argentinas; I, Floras liasicas. Ameghiniana, 7(1): 57-78

STOPES, M.C., 1910: The internal anatomy of "Nilssonia orientalis". Ann. Bot., 24: 389-393.

TIDWELL, W.D., 1986: Millerocaulis, a new genus with species formerly in Osmundacaulis Miller (Fossils: Osmundaceae). Sida, 11(4): 40I-405.

TIDWELL, W.D., 1987: A new species of Osmunda caulis ( $O$. jonesii $\mathrm{sp}$. nov.) from Tasmania, Australia. Rev. Palaeobot. Palynol, in press.

TIDWELL, W.D. \& JONES, R., 1987: Osmundacaulis nerii, a new osmundaceous species from Tasmania, Australia. Palaeontographica $B, 204$ : 181-191.

TOWNROW, J.A., 1963: A speculation of the RhaetoLiassic climate of Tasmania. Pap. Proc. R. Soc. Tasm., 98: 113-118.

TOWNROW, J.A., 1965: A new member of the Corystospermaceae Thomas. Ann. Bot. N.S., 29: $495-511$

(accepted 3 March 1987) 

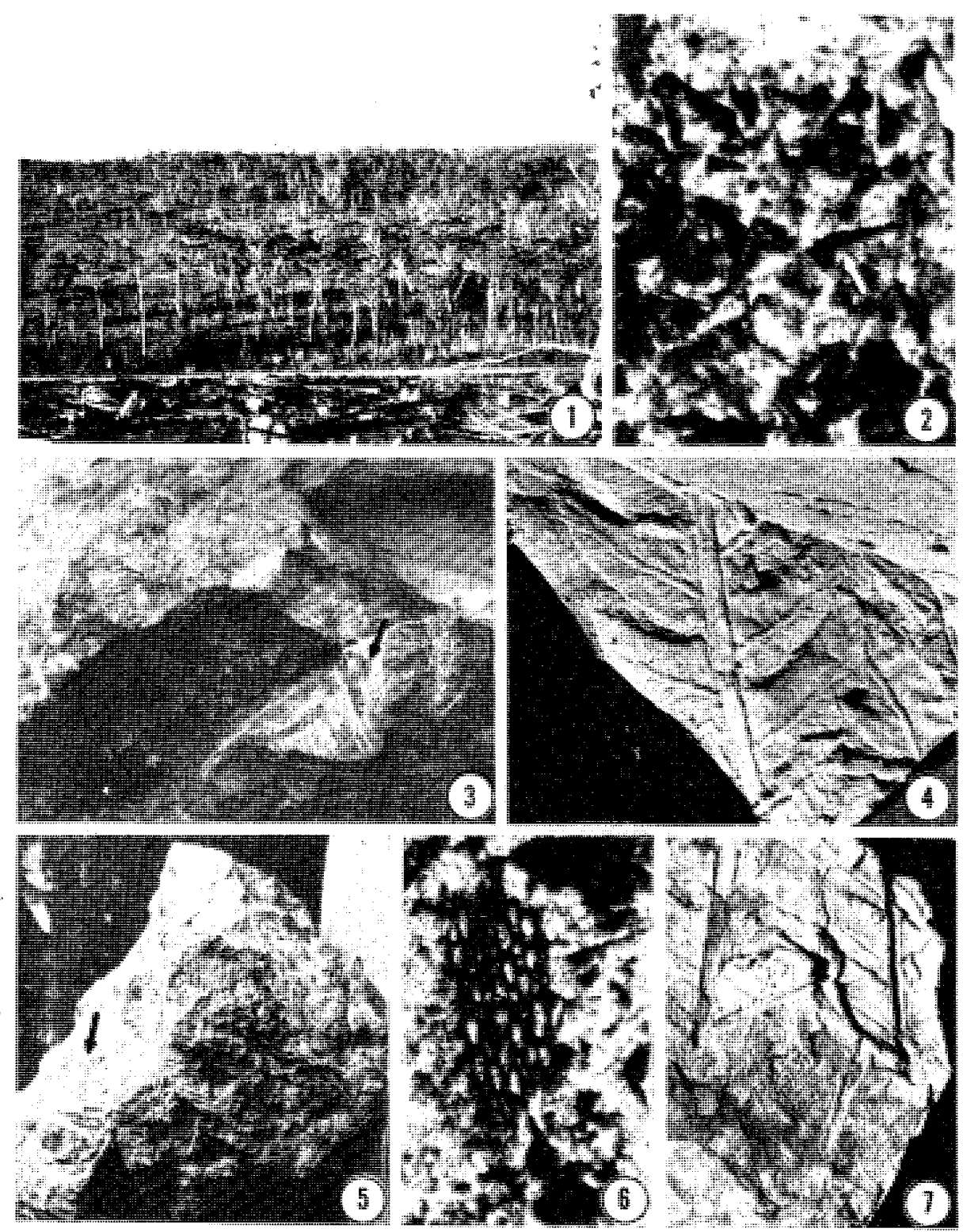

PLATE I

1. View of collecting locality. Collecting sites are in the flatiened area in the foreground and on the slopes in the background (photo by Ross Jones).

2. View of separale cone scales (arrow) of Conites sp. in the matrix of specimen Z2302: $\times 10$.

3. Portion of Pterophyllum? sp. showing pinna fragment (arrow), Z2302; $x 1.8$.
4. Pinnules of Cladophlebis indica (Oldham \& Morris) Sahni \& Rao, Z2298; $x 2.5$.

5. Pterophyllum? sp. pinna base (arrow), Z23030; $x 1$.

6. Cuticle of Otozamites $s p ., Z 2302 ; x 10$.

7. Pinnules of secondary pinnae of Cladophlebis indica (Oldham \& Morris) Sahni \& Rao, Z2297; $x 2$. 

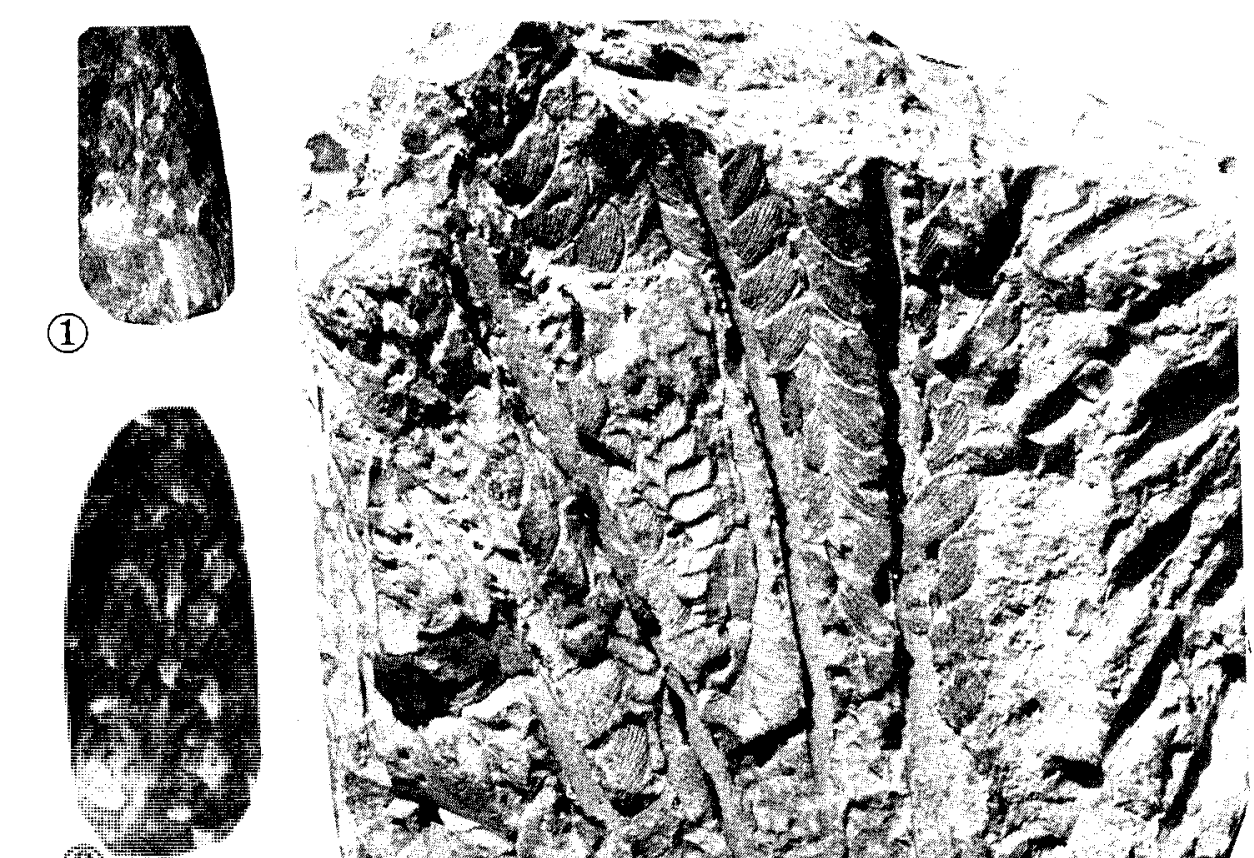

(2)

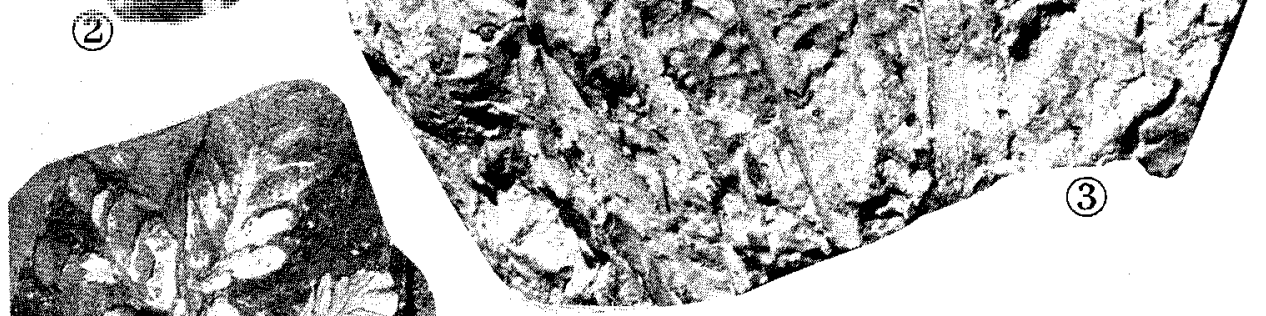

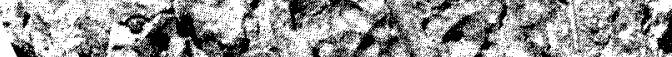
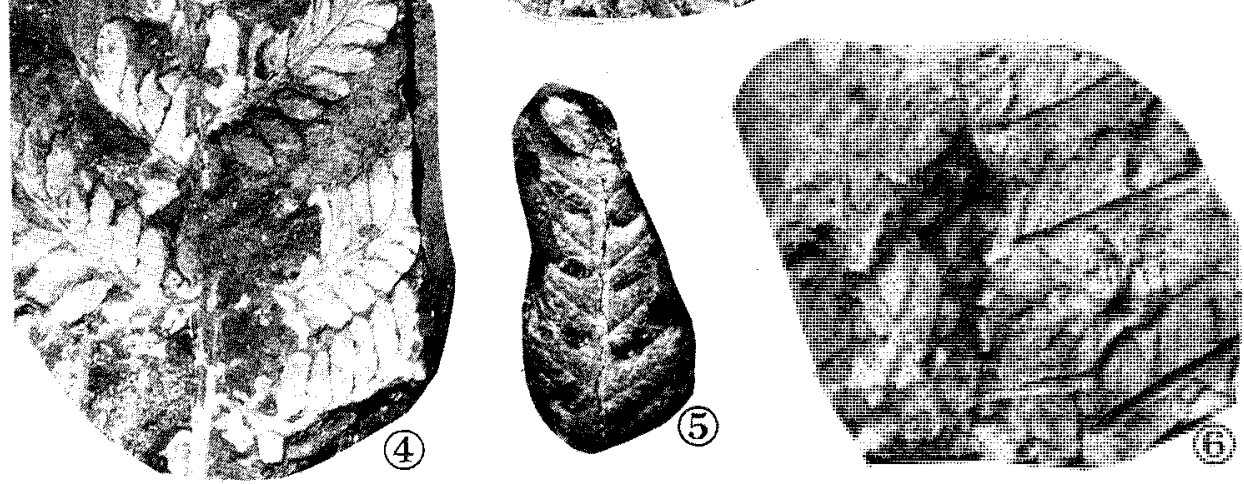

PLATE II

1-2 Coniopteris websterii sp. nov. 1, a fertile pinno fragment, Z2296; $x 2$ 2. enlargement of $1 ; x 4$.

3. Otozamites sp. A bundle of leaves consisting of more than 30 leaves preserved in parallel in the area of $50 \mathrm{~mm} \times 30 \mathrm{~mm}, 22302 ; \times 2$.
4. Pachypteris sp. cf. indica (Oldham \& Morris) Bose \& Roy, a bipinnate leaf fragment, Z2300.

5-6 Cladophlebis indica (Oldham \& Morris) Sahni \& Rao. 5, a pinna fragment, Z2298; $x 2.6, a$ bipinnate leaf fragment, Z2297; x 2 . 


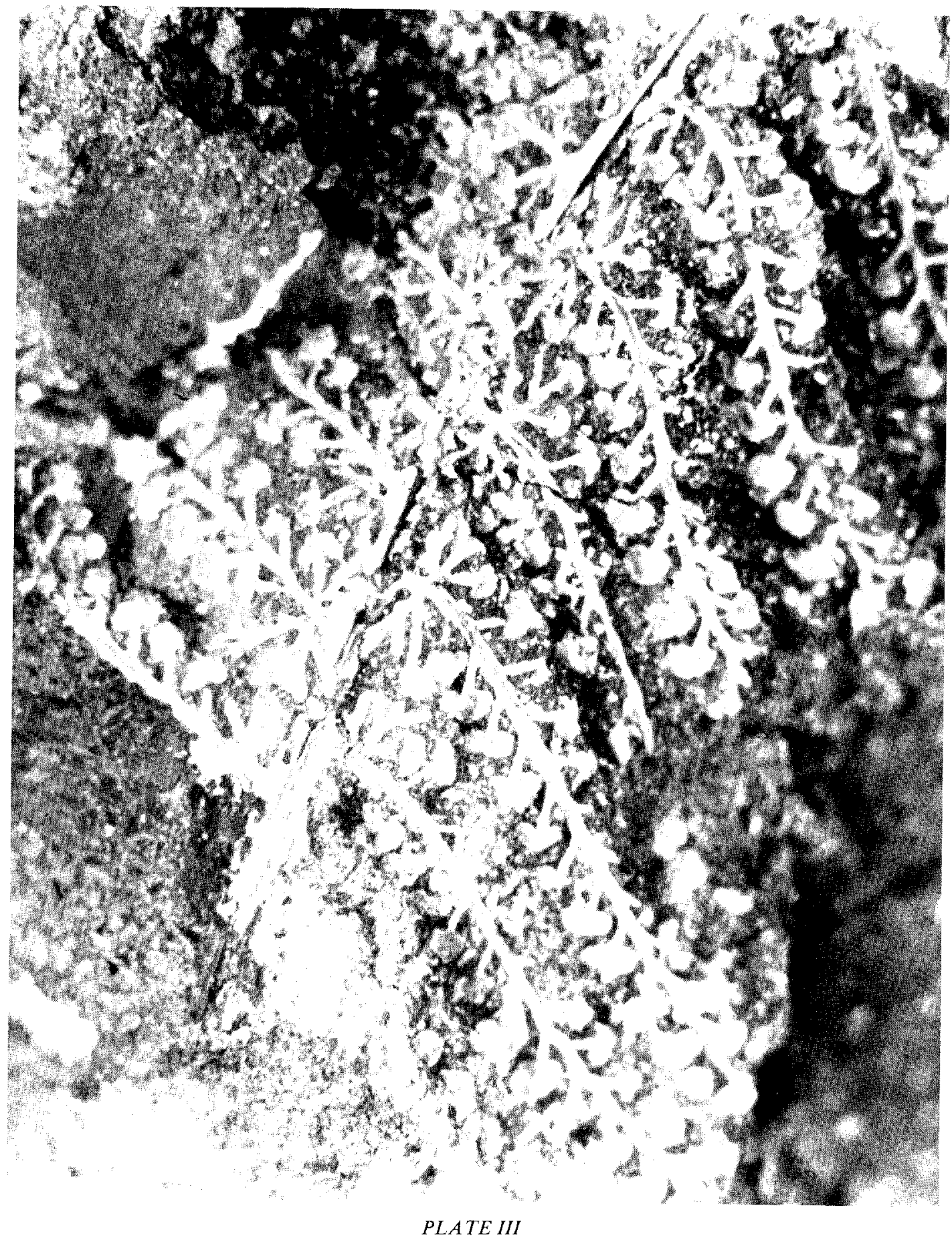

1. Coniopteris websterii sp. nov. (Specimen in the collection of Neri Webster); $x 4$. 